\title{
The Jesus of $K$ Road: Theological reflections on Māori and homelessness
}

\section{The Jesus of $K$ Road}

The Jesus of K Road talks to imaginary friends.

He doesn't have blue eyes

He has long and dirty fingernails

and toenails too.

An itchy, holey blanket is his robe.

He goes diving in the bins

not the moana

in search of bougie, free-range leftovers, empty compostable coffee cups and cardboard too.

He blesses the feet of passers by with inaudibale grunts and groans from his seated, lotus position. But no one sees this Jesus; he has the superpower of invisibility. 
No fixed abode.

No address.

No eftpos card.

No whenua.

A pariah in his own land.

As God's storyteller

he spins yarns

and weaves together pūrākau

-often indecipherable-

with hidden meanings, like Te Kooti's diamond!

He smokes weed and

drinks shaoxing cooking wine.

He shakes his offertory cup:

weed, wine and coins - the eucharistic elements of this, his Last Supper. 


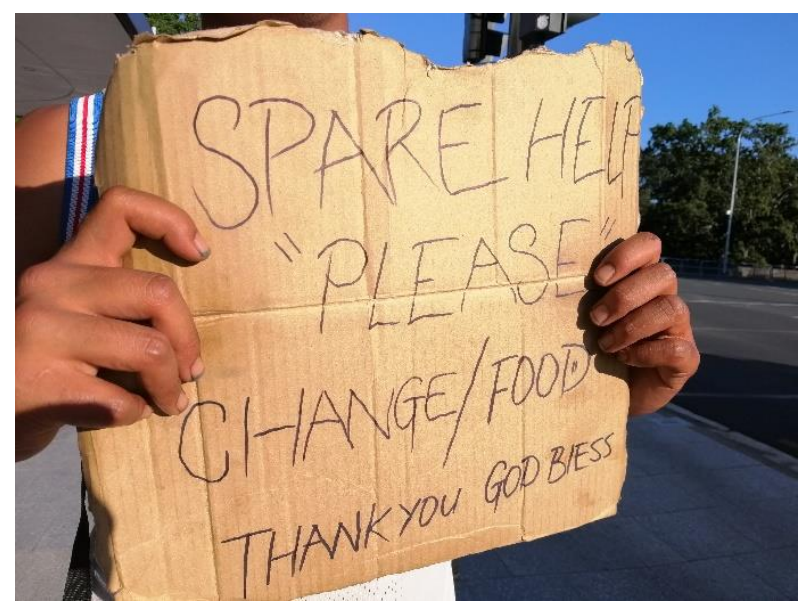

Figure 1. A sign used to ask motorists for helpKarangahape Road and Symonds Street intersection (B. Rangiwai, personal collection).

This paper reflects on my observations of, and casual discussions with, Māori experiencing homelessness, specifically, during the current lockdown in Auckland which began on 17 August 2021. It is important for those who experience homelessness to have their voices heard (Beaton et al., 2015). Amplifying these voices could increase understanding of the very complex issues that are faced (Beaton et al., 2015).

This paper begins with a poem entitled The Jesus of $K$ Road - a piece that expresses, through a theological lens, my observations of Māori experiencing homelessness. The Jesus of $K$ Road is a composite of the many characters I have had the 
privilege of meeting and speaking with. Nixon (2016) maintains that the homeless are God's storytellers, and this has certainly been my experience.

\section{The importance of whenua}

Brown (2016) argues that Māori homelessness originates with Māori landlessness. For Māori whenua is more than 'land'; "...it is much more than a mere resource; it is a large part of Māori mana as well as being the primary ancestor; it embodies the past and, at the same time, is the foundation for future generations" (Williams, 2004, p. 50). Marsden (2003) avers:

Whenua was the term both for the natural earth and placenta. This is a constant reminder that we are of the earth and therefore earthly. We are born out of the placenta and therefore human. As a human mother nourished her child in the womb and then upon her breast after the child's birth, so does Mother Earth (p. 68).

In most iwi the whenua, or placenta in this context, is buried in a place of significance; and at death, the remains are interred in the whenua (Rangiwai, 2015). "This symbolises interconnectedness between people and the land..." (Williams, 2004, p. 50) through genealogy and the cycle of life and death. Māori ancestors are therefore spiritually and physically anchored to the land (Rangiwai, 2015). Higgins (2012) states: "Land is one of the key 
elements to Māori identity. It embodies the histories, genealogies, and spiritual connections to the past, present, and future" (p. 412).

Whenua is a word that is intimately linked to Papatūānuku, wife of Ranginui; these are the primordial ancestors of ongoing influence from which Māori and all living things descend (Marsden, 2003; Moorfield, 2011; Williams, 2004). Marsden (2003) states: "Papatuanuku - 'Land from beyond the veil; or originating from the realm beyond the world of sense-perception', was the personified form of whenua - the natural earth" (p. 44).

As posterity of Papatūānuku, Māori are connected to the whenua through whakapapa (Rangiwai, 2015). Whakapapa connections to whenua are essential to Māori identity (Cheater \& Hopa, 1997; Higgins, 2012; Walker, 1990; Williams, 2004). Marsden (2003) contends:

Papatuanuku is our mother and deserves our love and respect. She is a living organism with her own biological systems and functions creating and supplying a web of support systems for all her children whether man, animal, bird, tree, grass, microbes or insects (p. 45).

Stressing the importance of Māori identity with whenua, Williams (2004) argues: "Māori are not just joined to the land, they are an integral part of nature, with a relationship to every other living thing, defined by whakapapa" (p. 50). Indeed, 
Mikaere (2011) maintains that from the perspective of a Māori world view, the entire universe is connected:

...the single most important message to emerge from our creation stories is that we are connected, by whakapapa, to one another and to all other parts of creation. Everything in the natural world, ourselves included, shares a common ancestry ( $p$. 313).

Commenting on Māori as children of Papatūānuku and the connections of all living things, Marsden (2003) maintains:

Papatuanuku's children live and function in a symbiotic relationship. From unicellular through to more complex multicellular organisms each species depends upon other species as well as its own, to provide the basic biological needs for existence. The different species contribute to the welfare of other species and together they help to sustain the biological functions of their primeval mother, herself a living organism (p. 45).

The Crown disrupted and damaged these links through various methods, beginning with the assertion of a pre-emptive right to purportedly 'unused' lands, included within the Treaty of Waitangi (Cheater \& Hopa, 1997; Orange, 2001; Walker, 1990). For those Māori who refused to sell their land, The Crown launched a barrage of attacks, and by 1900 the State had procured over 
ninety per cent of the country (Cheater \& Hopa, 1997; Walker, 1990). Separation of Māori from whenua caused widespread social, cultural, economic, and spiritual harm (Rangiwai, 2015).

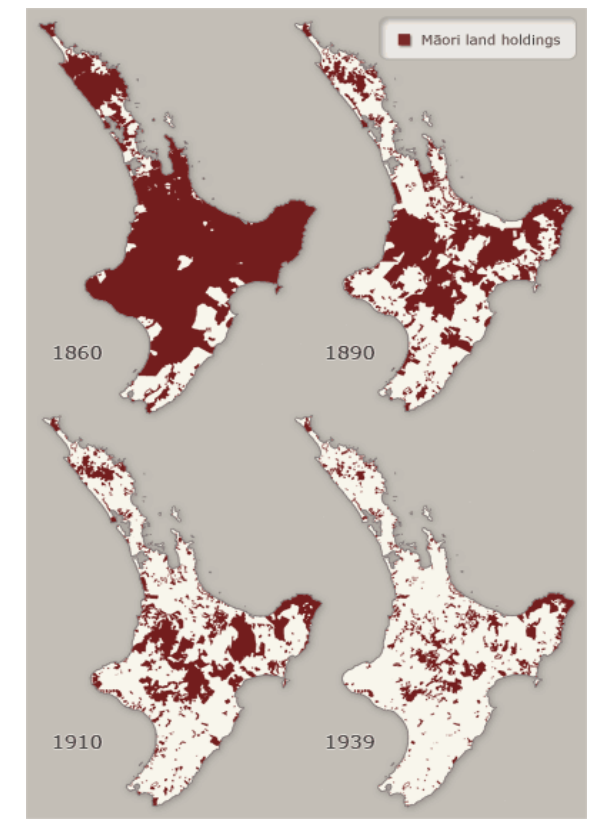

Figure 2. Gradual alienation of Mãori land (Orange, 2001, pp. 318-319).

\section{Māori and homelessness}

Homelessness ${ }^{1}$ has been an issue in urban life in Aotearoa New Zealand for more than a century

1 The term "homeless" can be problematic in that it suggests that those who are sleeping rough do not create "homes" for themselves on the streets (Beaton et al., 2015). Some, like 
(Groot \& Peters, 2016). Since Māori have endured more than 150 years of "being rendered out of place", homelessness is "endemic to experiences of colonialism" (Groot \& Peters, 2016, p. 323). Often caused by a physical separation from whānau, hapū and iwi, Māori may experience homelessness as cultural and spiritual disconnection (King et al., 2016). Māori who are homeless may experience intense levels of whakamā due to this disconnection (Groot et al., 2011).

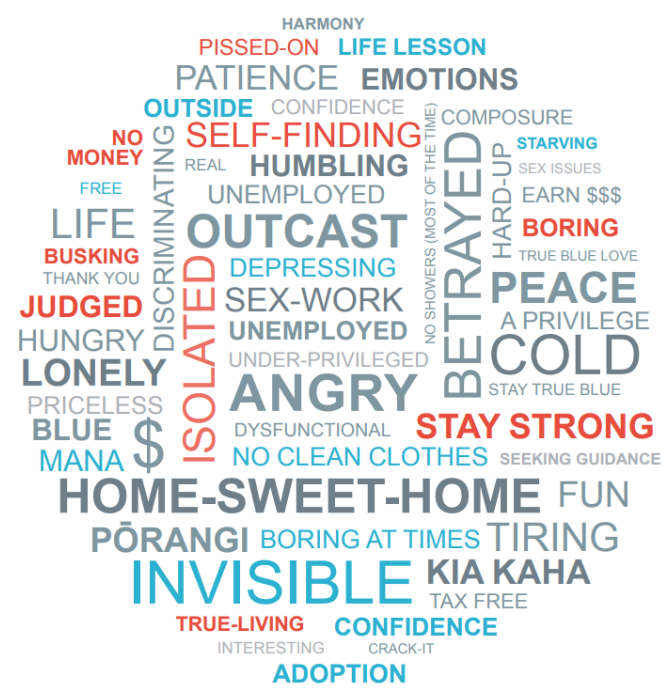

Figure 3. Experiences of sleeping rough (Beaton et al., 2015, p. 9).

Beaton et al. (2015) use the term "sleeping rough". However, following the examples of Brown (2016), Groot and Peters (2016), and King et al. (2016), this paper will use the terms "homeless" and "homelessness". 
Māori-like many other Indigenous populations around the world-are overrepresented in Aotearoa New Zealand's homeless population (Groot \& Peters, 2016). According to Groot and Peters (2016) "The colonial legacy of dispossession and exclusion also plays a role in exacerbating and maintaining Māori homelessness" (p. 328). If Māori landlessness is the root cause of Māori homelessness, then solutions for Māori homelessness must address Māori land loss (Brown, 2016).

The homeless live their lives out in the open and are often judged by the public. (Beaton et al., 2015). Some members of the public perceive being homeless to be a personal choice and this perception is used as a reason not to help; it is also believed that the welfare system provides the homeless with "financial rewards beyond what could be attained in the paid workforce" (Beatson et al., 2015, p. 15).

For those who are homeless, on the other hand, the notion of choice was understood and expressed in terms of self-determination (Beaton et al., 2015). However, the choices themselves are difficult: to remain in situations of insufferable abuse or to become homeless (Beaton et al., 2015).2 Others in

2 For some, homelessness was preferred, due to experiences of abuse and neglect, often at the hands of family; feeling disconnected from family and the broader community was also a factor (Beaton et al., 2015). 
the public were more empathetic and believed that central and local government, non-government agencies, and the wider community, had a responsibility to support those who are homeless (Beaton et al., 2015).

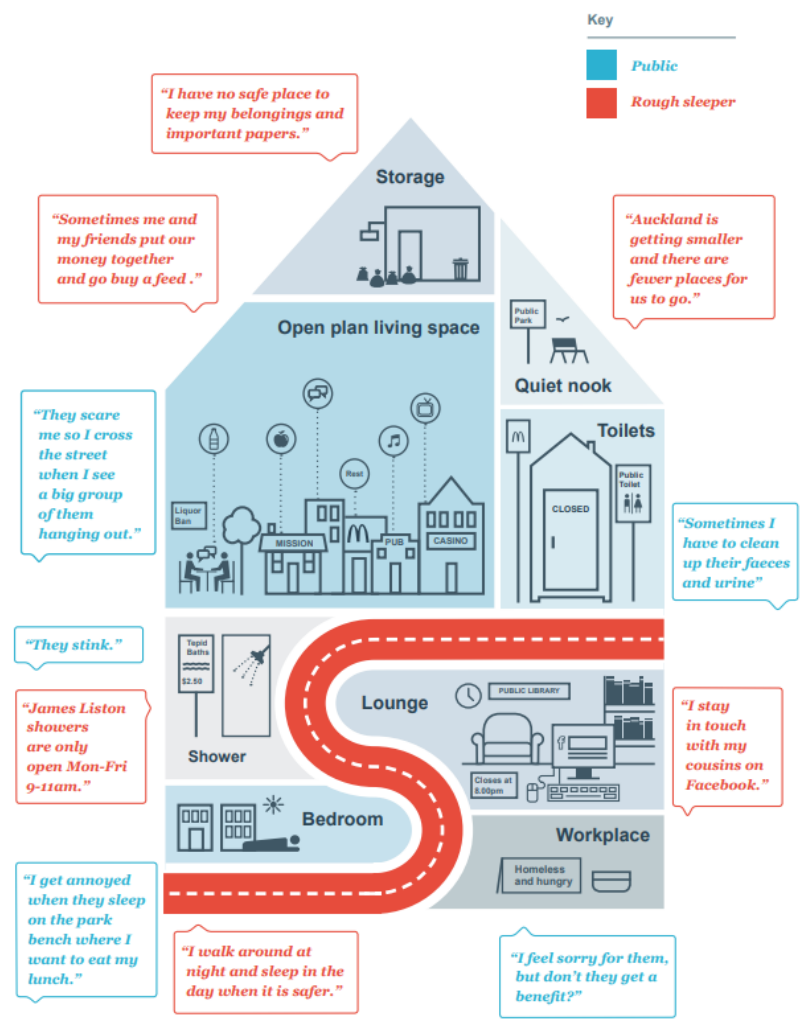

Figure 4. Public and private domains meet on the street (Beaton et al., 2015, p. 11). 
The pathways to homelessness include family violence, family breakdown, job loss, eviction from housing, leaving prison, foster runaways, poor mental health, alcoholism and drug addiction, and exiting gangs (Beaton et al., 2015, p. 4). Coping mechanisms for homelessness include begging/busking/hustling, ${ }^{3}$ drugs and alcohol, theft, sharing food with others in the homeless community, free food, fishing, and sex work (Beaton et al., 2015, p. 4). The ways in which the homeless create homes for themselves on the streets include gaining knowledge of street culture, becoming independent, developing a street whānau/family, creating friendships/forming bonds, finding support from social workers, developing a role/identity or reputation on the streets (Beaton et al., 2015, see p. 5).

${ }^{3}$ Hustling refers to making money in ways outside the formal economy (Cottom, 2020) and has historically been associated with drug dealers, sex workers, and 'undesirable' street corner activities (Ens, 2021; Mitchell, 2021; Sheaffer, 2021). 


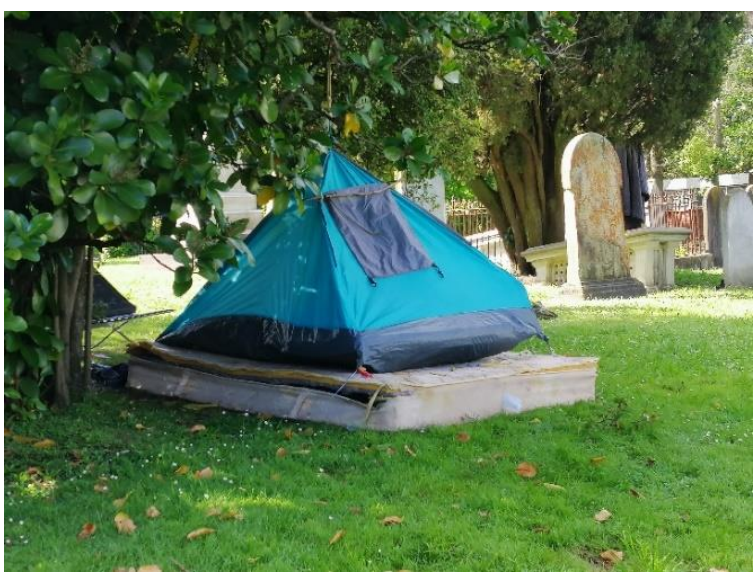

Figure 5. An innovative home-space created with a small tent placed on a mattress-Symonds Street Cemetery, Jewish section (B. Rangiwai, personal collection).

Atua, whenua, tangata: Landlessness and homelessness from a Māori theological perspective As Brown (2016) points out, homelessness for Māori begins with landlessness. The whenua is essential to Māori identity (Rangiwai, 2015) and provided an economic base that was removed as part of the colonisation process (Groot \& Peters, 2016). The effects of land loss and landlessness are both severe and ongoing for Māori (Rangiwai, 2015) and contribute to the continuing issues of Māori homelessness (Brown, 2016; Groot \& Peters, 2016; King et al., 2016). 


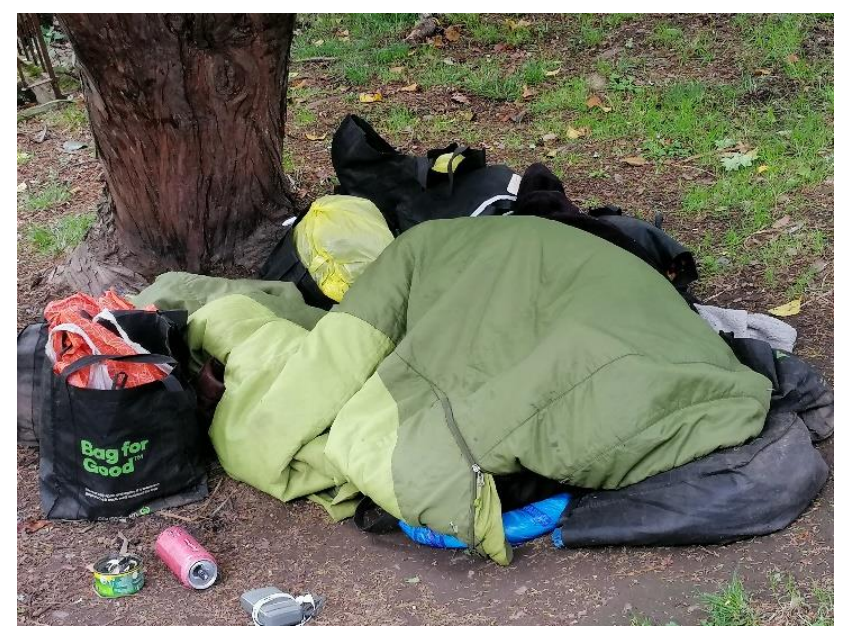

Figure 6. Sleeping arrangements under a tree-Symonds Street Cemetery, Anglican section (B. Rangiwai, personal collection).

Whenua is critical to Māori theological understandings (Rangiwai, 2018a, 2019). The late Pā Henare Tate (2012) created a model that demonstrates the interrelationship of Atua, tangata and whenua (pp. 38-40; see figure 7). Tate (2012) used the term Atua to describe the God of the Bible in his model. The word tangata refers to human beings, or to a person, while the term whenua refers to land. For Tate (2012), "whenua provides sustenance for tangata and all other living creatures. It gives tangata a sense of identity and belonging" (p. 39). 
Tate (2012) argued that our Māori relationships with Atua, tangata and whenua are "dynamically related" (p. 38) and define who we are. According to Tate (2012), "If one enhances one's relationship with Atua, also enhanced will be one's relationship with tangata and whenua" (p. 38) and vice versa. He also contended that the same is true if one begins with whenua or tangata as a starting point.

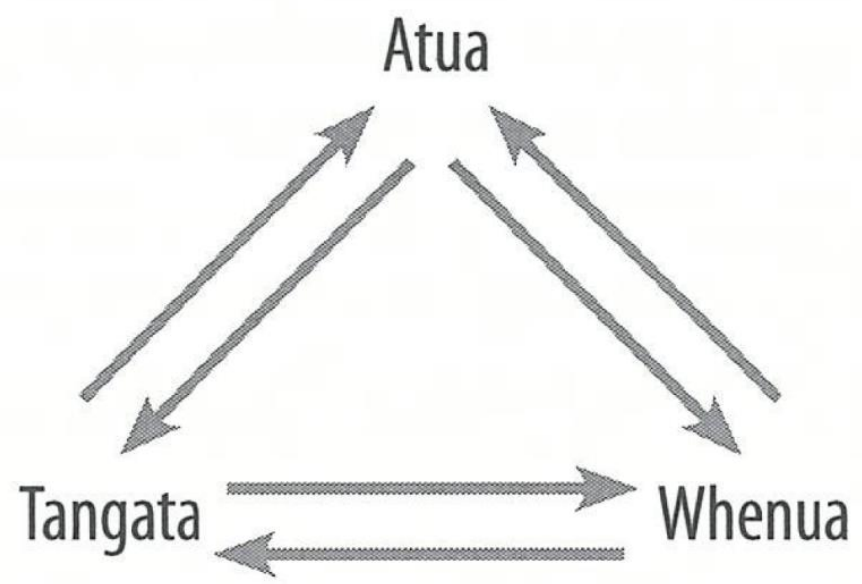

Figure 7. Atua, Tangata, Whenua Model(Tate, 2012, $p$. 38).

As a means of expanding Tate's (2012) work, I created the Atuatanga Model which draws architecturally and theologically on his model. However, there are significant differences. In the Atuatanga Model, there is no distinction made 
between ngā Atua Māori-the ancestors of continuing influence, sometimes described as departmental gods, and Te Atua-the Christian God; rather, Atuatanga refers to and includes both (Rangiwai, 2018a, 2019).

The concepts of tangata and whenua are the same as those expressed by Tate (2012), excepting an additional meaning to the word whenua, which engenders an important theological consideration (Rangiwai, 2018a, 2019). Tate (2012) commented on the importance of land for the provision of sustenance for all life on the earth. However, whenua is a term that means both land and human placenta; the double meaning of this word points to the significance of Māori connections to land (Rangiwai, 2018a, 2019). This extra layer of meaning connects Māori to the land genealogically, physically, and spiritually, as whenua is a cultural concept and cultural reality that concomitantly names land and placenta and addresses the links between Papatūānuku and Māori (Rangiwai, 2018a, 2019). 


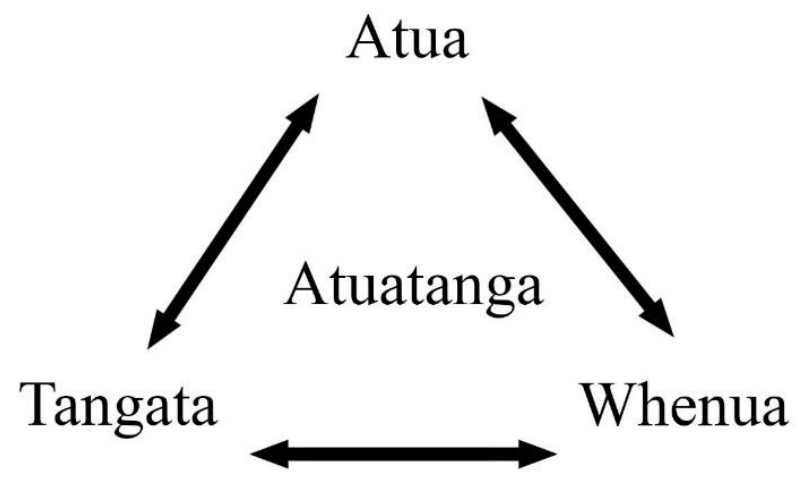

Figure 8. Atuatanga Model(Rangiwai, 2018a, p. 184).

Atuatanga 4 is the central theological concept in the Atuatanga Model. The dynamic triangulation of the aspects of this model expresses a Māori theological

\footnotetext{
4 From a theological point of view, Melbourne (2011) described Atuatanga as pre-European theology, Māori spirituality, theology from a Māori perspective, and the study of God from a Māori perspective. He contended that Atuatanga might be understood as an attempt by some Māori to understand the God of the Bible through Māori understandings, and as an attempt by others to bring together and reconcile the beliefs of traditional Māori with those of Christianity. Furthermore, Hollis (2013) expounded that Atuatanga may refer to the domain over which Te Atua or ngā Atua express authority. The term may represent, he claimed, the characteristics and the study of ngā Atua or Te Atua. He stated: "Atuatanga has been equated to the English word theology and some te reo Māori experts considered it to be the closest word in te reo Māori to the Greek derivative of [the word] theology" (Hollis, 2013, p. x).
} 
reality based on the interdependent relationships between Atua (ngā Atua and Te Atua), tangata and whenua.

For Māori, homelessness ultimately originates with landlessness (Brown, 2016). Whenua is essential to Māori identity and wellbeing (Rangiwai, 2015) and so without whenua, or when disconnected from whenua, the theological and spiritual connections between Atua, tangata and whenua is disrupted. Without connection to whenua, therefore, a Māori person is essentially incomplete.

\section{Significance of The Jesus of $\mathrm{K}$ Road}

If God had a face, what would it look like?

And would you want to see?

If seeing meant that you would have to

believe

In things like heaven and in Jesus and the saints and all the prophets?

Joan Osborne (1995) 


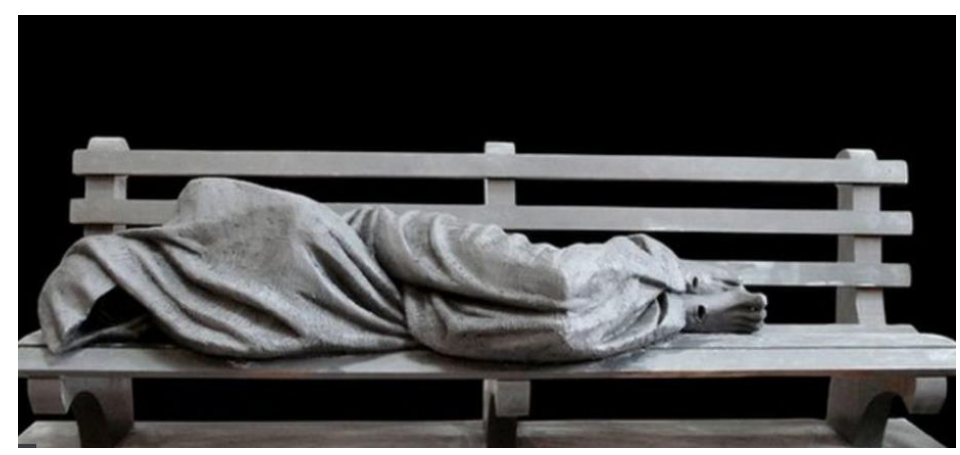

Figure 9. Homeless Jesus by Timothy Schmalz (McCann, 2014, n.p.).

Osborne's (1995) song calls to mind a profound and poignant question: what does the face of God look like? (Rangiwai, 2018b). Furthermore: what does the face of Jesus, as God incarnate, look like? Does he look like me? Is he Māori? (Rangiwai, 2018b). Is Jesus landless? Is Jesus homeless? Like the confronting and controversial image, based on the Gospel of Mathew, of Homeless Jesus (see Figure 9) by Timothy Schmalz (Baluk, 2021), the homeless people of K Road-most of whom are overwhelmingly Māori-are a reminder to us of the consequences of oppression. New Testament scholarship often presents a romanticised view of Jesus' homelessness as a choice (Myles, 2014). However, Myles (2014) argues that Jesus' homelessness in the Gospel of Mathew should be analysed in relation to the political, economic, and social context of the day. Based on a critical re-reading of the Gospel of 
Mathew, Myles (2014) opines that, like the homeless people of today, Jesus was a displaced and disposable outcast.

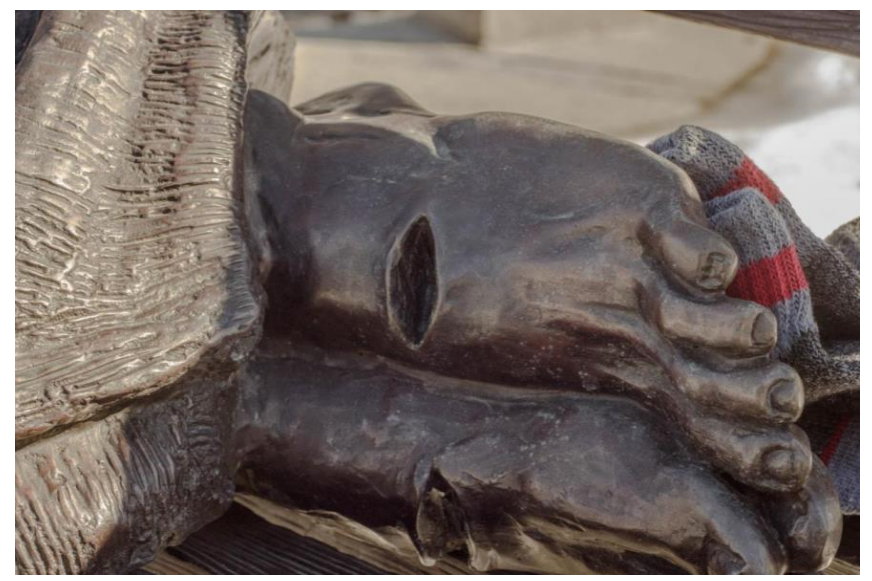

Figure 10. Photo of feet wounds of Homeless Jesus by Baluk (2021, p. 100) at St Patrick's Roman Catholic Church in Hamilton, Ontario. Note: socks have been left by a previous viewer of the sculpture.

The Jesus of $K$ Road and Homeless Jesus both present images of Jesus in context. While Schmalz's bronze sculpture represents an "uncomfortable but familiar" call to the faithful to "be compassionate and humble" when caring for those who are homeless (Baluk, 2021), The Jesus of K Road and the people and expressions represented therein, are 
a reminder that God, and God's storytellers (Nixon, 2016), can be found on the streets (see Figure 11).

\begin{abstract}
B) Byron Rangiwai
November 4 at 4:21 PM - :

Got a bit teary just now cos a homeless Maori woman offered me food and drink and asked if I was okay. It should be the other way around.

I was reminded of Mark 12:41-44.

Jesus sat down opposite the treasury, and watched the crowd putting money into the treasury. Many rich people put in large sums. A poor widow came and put in two small copper coins, which are worth a penny. Then he called his disciples and said to them, 'Truly I tell you, this poor widow has put in more than all those who are contributing to the treasury. For all of them have contributed out of their abundance; but she out of her poverty has put in everything she had, all she had to live on.'
\end{abstract}

Figure 11. Facebook post from 4 November 2021.

This brief paper has presented some reflections of homelessness from a Māori theological perspective. There is a distinct need for further research and for the development of a Māori theology of homelessness. This paper has provided a humble beginning point. 


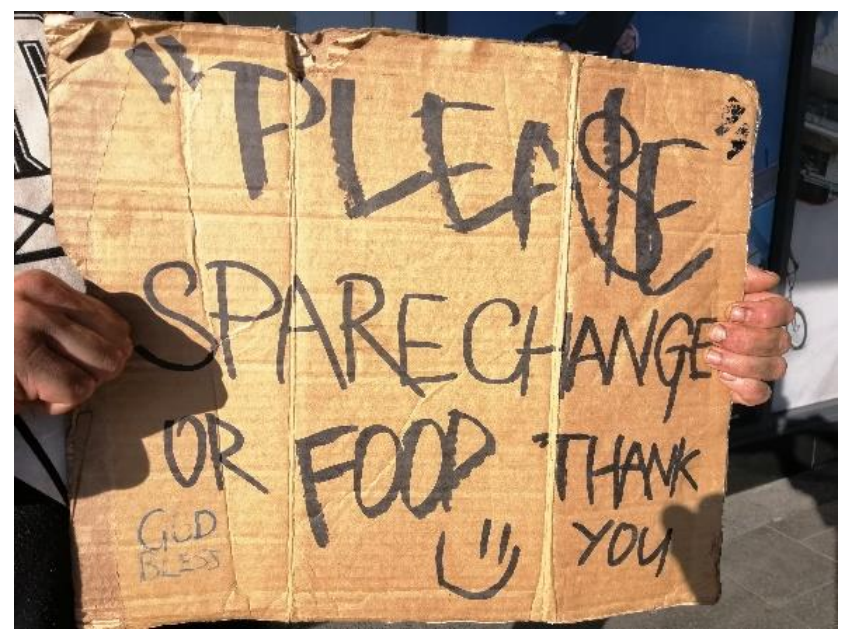

Figure 12. A sign used to ask motorists for helpKarangahape Road (B. Rangiwai, personal collection). 


\section{References}

Baluk, K. W. (2021). Homeless Jesus: Exploring a relationship between publica religious art and public dialogues on homelessness [Unpublished doctoral thesis]. McMaster University. https://macsphere.mcmaster.ca/handle/11375 $\lcm{26307}$

Beaton, S., Cain, T., Robinson, H., Hearn, V. (2015). An insight into the experience of rough sleeping in central Auckland. Lifewise, Auckland Council, Auckland City Mission, ThinkPlace. https://www.lifewise.org.nz/wpcontent/uploads/2016/01/rough-sleepingreport.pdf

Brown, D. (2016). Tūrangawaewae kore: Nowhere to stand. In E. J. Peters \& J. Christensen (Eds.), Indigenous homelessness: Perspectives from Canada, Australia, and New Zealand (pp. 331362). University of Manitoba Press.

Cheater, A. \& Hopa, N. (1997). Representing identity. In A. James, J. Hockey \& A. Dawson (Eds.), After writing culture: Epistemology and praxis in contemporary anthropology (pp. 208-23). Routledge.

Cottom, T. M. (2020). The hustle economy. Dissent, 67(4), 19-25. https://doi.org/10.1353/dss.2020.0094

Ens, N. (2021). Tales of hustling in the digital economy. Paper presented at The Hustle 
Economy: Race, gender, and digital entrepreneurship.

https://datasociety.net/announcements/2021/

$01 / 26 /$ the-hustle-economy-race-gender-anddigital-entrepreneurship/

Groot, S., Hodgetts, D., Nikora, L. M., \& Rua, M. (2011). Māori and homelessness. In T. McIntosh $\&$ M. Mulholland (Eds.), Māori and social issues (pp. 235-262). Huia.

Groot, S. \& Peters, E. J. (2016). Indigenous homelessness: New Zealand context. In E. J. Peters \& J. Christensen (Eds.), Indigenous homelessness: Perspectives from Canada, Australia, and New Zealand (pp. 324-330). University of Manitoba Press.

Higgins, R. (2012). New Zealand: The Māori people. In M. D. Palmer \& S. M. Burgess (Eds.), The WileyBlackwell companion to religion and social justice (pp. 412-424). Blackwell Publishing.

Hollis, J. T. (2013). Te Atuatanga: Holding Te Karaitianatanga and Te Māoritanga together going forward (Unpublished doctoral thesis). University of Canterbury.

King, P., Hodgetts, D., Rua, M., \& Te Whetu, T. (2016). Emplaced cultural practices through which homeless men can be Māori. In E. J. Peters \& J. Christensen (Eds.), Indigenous homelessness: Perspectives from Canada, Australia, and New Zealand (pp. 363-388). University of Manitoba Press. 
Marsden, M. (2003). The woven universe: Selected writings of Rev. Māori Marsden. Ōtaki, New Zealand: Estate of Rev. Māori Marsden.

McCann, N. (2014, 27 December). Tim Schmalz seeks home for his homeless Jesus. BBC News. https://www.bbc.com/news/uk-northernireland-30432842

Melbourne, T. (2011). Te wairua kōmingomingo o te Mãori: The spiritual whirlwind of the Mãori (Unpublished doctoral thesis). Massey University. Mikaere, A. (2011). Colonising myths - Māori realities: He rukuruku whakaaro. Huia Publishers \& Te Tākupu, Te Wānanga o Raukawa.

Mitchell, G. (2021). Street hustling in Brazil. In J. Scott, C. Grov \& V. Minichiello (Eds.), The Routledge handbook of male sex work, culture, and society. Routledge. https://doi.org/10.4324/9781003152835

Moorfield, J. C. (2011). Te Aka-Māori-English, English-Māori dictionary. Pearson.

Myles, R. J. (2014). The homeless Jesus in the Gospel of Mathew. Sheffield Phoenix Press.

Nixon, D. (2016). Stories from the street: A theology of homelessness. Routledge.

Orange, C. (2001). Ilustrated history of the Treaty of Waitangi. Bridget Williams Books.

Osborne, J. (1995). One of us. Relish. The Crawlspace.

Rangiwai, B. (2015). Ko au ko Te Umutaoroa, ko Te Umutaotoa ko au: Toward a Patuheuheu hapū 
development model [Unpublished doctoral thesis]. Auckland University of Technology. https://openrepository.aut.ac.nz/handle/10292 $\angle 8851$

Rangiwai, B. (2018a). The Atuatanga model: A methodology for researching Māori theology. Te Kaharoa: The eJournal on Indigenous Pacific Issues, $11(1)$, 181-194. https://www.tekaharoa.com/index.php/tekahar oa/article/view/191

Rangiwai, B. (2018b). Karaititanga: Some reflections on my Christology. Te Kaharoa: The eJournal on Indigenous Pacific Issues, 11(1), 591-603. https://www.tekaharoa.com/index.php/tekahar oa/article/view/238

Rangiwai, B. (2019). A Kaupapa Māori study of the positive impacts of syncretism on the development of Christian faith among Māori from my faith-world perspective [Unpublished doctoral thesis]. University of Otago. https://ourarchive.otago.ac.nz/handle/10523/ 9847

Sheaffer, R. (2021). Gigolos in popular cinema. In J. Scott, C. Grov \& V. Minichiello (Eds.), The Routledge handbook of male sex work, culture, and society. Routledge. https://doi.org/10.4324/9781003152835

Tate, H. (2012). He puna iti $i$ te ao mārama: A little spring in the world of light. Libro. 
Walker, R. (1990). Ka whawhai tonu matou: Struggle without end. Penguin.

Williams, J. (2004). Papa-tūā-nuku: Attitudes to land. In T. M. Ka'ai, J. C. Moorfield, M. P. J. Reilly $\&$ S. Mosley (Eds), Ki te whaiao: An introduction to Māori culture and society (pp. 50-60). Pearson. 